\title{
Studi eksperimental karakteristik semprotan air pada airblast atomizer
}

\author{
I Dewa Gede Putra Swastika \\ Program Studi Teknik Mesin Universitas Udayana, Kampus Bukit Jimbaran, Bali \\ Naskah diterima 25/03/2020; direvisi 06/04/2020; disetujui 16/04/2020 \\ doi: https://doi.org/10.24843/JEM.2020.v13.i01.p08
}

\begin{abstract}
Abstrak
Pengujian eksperimental telah dilakukan untuk mengamati karaktristik semprotan air pada airblast atomizer. Atomiser yang diuji merupakan nosel yang digunakan untuk keperluan pembakaran (burner). Untuk atomiser tipe ini cairan dan udara bercampur di dalam nosel sebelum disemprotkan ke lingkungan (ambient air). Air yang digunakan dalam pengujian mewakili bahan bakar pada burner yang sebenarnya, disuplai menggunakan pompa sedangkan udara disuplai menggunakan kompresor. Pengujian dilakukan dengan beberapa variabel, yaitu rasio udara dan air, tekanan injeksi air, dan pengujian pemanasan awal air sebelum bercampur dan disemprotkan ke lingkungan. Pengujian ini merekam gambar evolusi semprotan menggunakan kamera berkecepatan tinggi pada $1000 \mathrm{fps}$ dengan durasi 2 detik dan ukuran gambar $1244 \times 240$ pixels. Hasil pengujian menunjukkan bahwa variabel-variabel pengujian mempengaruhi karakteristik atomisasi yang terjadi (dimensi spray dan tingkat penguapan). Hasil pengujian juga dijelaskan dalam analisis gambar evolusi semprotan mulai dari kemunculan awal di ujung nosel sampai terbentuk spray yang stabil. Analisis gambar evolusi spray menunjukkan bahwa rasio udara-air yang tinggi menghasilkan sudut semprotan yang kecil, atomisasi yang lebih cepat, dan ukuran droplet yang lebih kecil.
\end{abstract}

Kata Kunci: air blast atomizer, spray, atomization

\section{Abstract}

Experimental testing has been carried out to observe the characteristics of water spray on the airblast atomizer. The atomiser tested is a nozzle used for burners. For this type of atomiser the liquid and air mix in the nozzle before being sprayed into the environment (ambient air). The water used in the test represents the fuel in the actual burner, it is supplied using a pump while the air is supplied using a compressor. The test is carried out with several variables, namely the ratio of air and water, water injection pressure, and preheating water test before mixing and spraying into the environment. This test records the evolution of the spray using a high-speed camera at $1000 \mathrm{fps}$ with a duration of 2 seconds and images size of $1244 \times 240$ pixels. The test results show that the test variables affect the characteristics of the atomisation (spray dimensions and evaporation rate). The test results are also explained in the analysis of spray evolution images starting from the initial appearance at the tip of the nozzle to forming a stable spray. Analysis of spray evolution images shows that high air-water ratios produce smaller spray angles, faster atomization, and smaller droplet sizes.

Keywords: air blast atomizer, spray, atomization

\section{Pendahuluan}

Salah satu peralatan yang digunakan untuk mengatomisasi cairan menjadi butiran air dalam ukuran kecil (disebut droplet) adalah nosel. Nosel digunakan untuk berbagai keperluan seperti atomisasi bahan bakar dalam pembakaran; atomisasi air dalam pemadaman kebakaran, pendinginan, pengairan, pertanian (pupuk dan pestisida) dan keperluankeperluan lainnya. Dalam aplikasi pembakaran nosel digunakan dalam burner yang sederhana maupun yang memiliki desain kompleks. Nosel bisa digunakan dengan mnyuplai cairan saja, sehingga atomisasi dan pencampuran dengan udara terjadi di luar nosel terjadi secara alami; ataupun dengan menyuplai cairan dan udara menuju nosel dengan pengontrolan campuran udara dan cairan yang lebih baik sesuai yang dikehendaki.

Demikian juga dengan aplikasi pembakaran, pada nosel dengan suplai bahan bakar saja maka atomisasi dan pencampuran dengan udara terjadi di luar nosel secara alami dan spontan, sehingga kualitas pembakaran lebih sulit dikontrrol. Tipe nosel yang demikan disebut pressure atomizer.

Dari pengamatan yang telah dilakukan, penggunaan Kompor Pembakar Jenazah dalam upacara Ngaben menggunakan nosel dan pembakaran tipe tersebut. Kompor pembakaran jenazah terdiri dari nosel, selang saluran bahan bakar, tangki bahan bakar dan kompresor. Kompor ini dioperasikan dengan memanfaatkan udara yang dikompresi oleh kompresor pada tangki bahan bakar untuk mengalirkan bahan bakar menuju nosel untuk diatomisasikan dan dibakar. Pengoperasian kompor dengan cara tersebut menimbulkan inkonsistensi terhadap campuran udara dan bahan bakar. Dalam proses pembakaran secara kontinu, volume bahan bakar pada tangki akan semakin berkurang sementara volume udara meningkat dan mengakibatkan udara dalam jumlah yang tidak terukur ikut dialirkan menuju nosel.

Proses pembakaran yang baik tentunya sangat dipengaruhi oleh campuran udara dan bahan bakar. 
Oleh karena itu, dalam upaya memperbaiki proses pencampuran udara dan bahan bakar pada Kompor Pembakar Jenazah dilakukan pergantian nosel berjenis pressure atomizer dengan airblast atomizer yang memiliki dua saluran fluida, yaitu udara dan cairan (liquid), sehingga memungkinkan untuk melakukan kontrol terhadap udara dan cairan (liquid).

Pada tahap awal penelitian ini akan menguji karakteristik spray dari nosel yang telah dibuat, menggunakan liquid berupa air untuk mewakili bahan bakar cair. Hal ini dikarenakan karakteristik spray yang diuji berfokus pada bentuk spray dan penguapannya; tanpa terjadi pembakaran. Dalam penelitian ini aliran air dijaga dengan debit $200 \mathrm{ml} /$ menit, sedangkan aliran udara divariasikan masing-masing 200, 400, 600, 800 dan $1000 \mathrm{ml}$ per menit; yang berkesesuaian dengan rasio udara-cairan $1: 1,2 ; 1,3: 1,4: 1$, dan $5: 1$.

\section{Dasar Teori}

Atomisasi merupakan proses disintegrasi pada cairan untuk mengubah bentuk cairan menjadi butiran atau (droplet). Adapun tujuan dari atomisasi adalah untuk meningkatkan luas permukaan cairan. Tahapan atomisasi dapat dilihat pada Gambar 1, prosesnya dimulai dari keluarnya cairan dari ujung nosel dalam bentuk lembaran (sheet), kemudian membentuk ikatan (ligament) yang kemudian terdisintegrasi menjadi butiran (droplet) [1, 2].

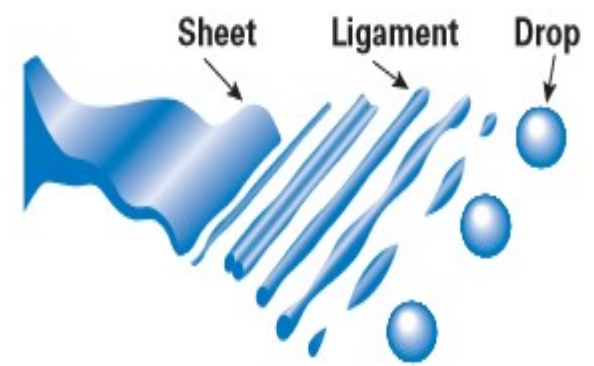

Gambar 1. Tahapan atomisasi

Kumpulan droplet yang terbentuk dari hasil atomisasi akan membentuk semburan (spray) dengan karakteristik tertentu. Dalam proses pembakaran beberapa karakteristik semburan sangat mempengaruhi, seperti ukuran sebaran butir, sudut semburan dan pola semburan [3]. Beberapa faktor lain yang mempengaruhi karakteristik spray adalah sifat zat cair yang meliputi tegangan permukaan, viskositas, dan densitas [1].

Tegangan permukaan dan viskositas cenderung mensatabilkan cairan dan mencegah terjadinya atomisisasi. Hal ini disebabkan oleh adanya gaya kohesi yang menimbulkan ikatan yang rapat antara molekul cairan. Oleh karena itu, pada umumnya cairan dengan tegangan permukaan dan viskositas yang tinggi akan menghasilkan droplet berukuran relative besar. Densitas cairan yang tinggi akan cenderung mempertahankan akselerasi cairan, di mana hal ini juga akan mencegah terjadinya proses atomisasi. Densitas yang lebih tinggi cenderung menghasilkan ukuran droplet yang lebih besar [4].

Sudut semburan (spray angle) merupakan besar sudut yang terbentuk pada semburan. Besar sudut semburan dipengaruhi oleh sifat zat cair, tekanan cairan, ukuran droplet, dan bentuk geometri nosel [5].
Pada penggunaan kompor jenazah untuk upacara Ngaben saat ini, atomisasi dan karkteristik spray belum mendapatkan perhatian, melainkan hanya mengutamakan manfaat pembakaran yang dihasilkan, yaitu energi panas. Hal ini ditunjukkan oleh kontrol campuran udara dan bahan bakar dan jenis pembakaran yang dilakukan. Kontrol campuran hanya dilakukan secara visual berdasarkan nyala api pembakaran yang terjadi tanpa mempertimbangkan spray dan komposisi udara dan bahan bakar yang terjadi. Pembakaran yang digunakan pada kompor adalah diffusion combustion dengan memanfaatkan udara atmosfer untuk pembakaran [6], hal ini mengakibatkan jumlah udara yang dibakar tidak terkontrol.

Penggunaan Airblast Atomizer pada penelitian ini bertujuan untuk mengubah jenis pembakaran diffusion combustion menjadi premixed combustion, dengan tujuan pengontrolan campuran udara-bahan bakar yang lebih baik diharapkan menghasilkan pembakaran yang lebih baik juga. Gambar Skematik airblast atomizer ditunjukkan dalam Gambar 2.

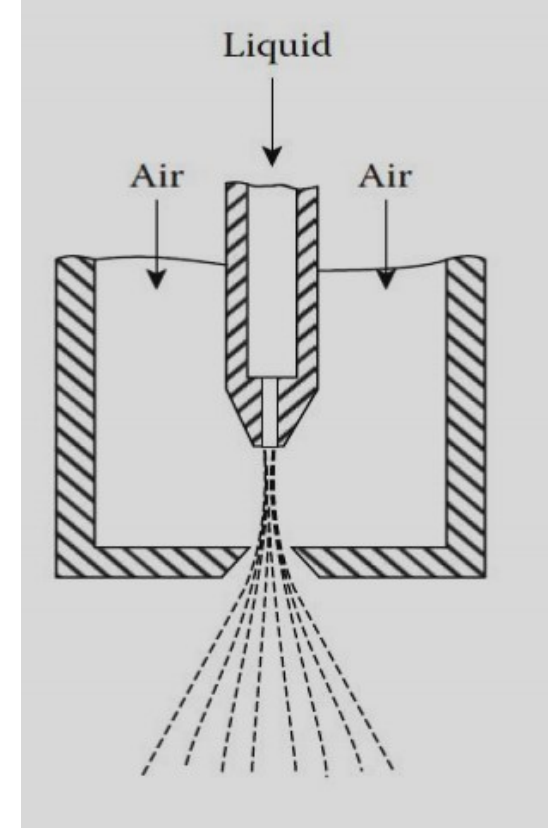

Gambar 2. Skematik airblast atomizer $[7,8]$

\section{Metode Penelitian}

Dalam penelitian ini dua macam pengujian dilaksanakan untuk mengetahui tingkat atomisasi dan karakteristik spray pada Airblast Atomizer.

Pengujian pertama, bertujuan mengetahui bentuk geometri semburan (spray) dari awal injeksi sampai spray (semburan) terbentuk dengan stabil. Pengujian ini dilakukan merekam proses atomisasi yang terjadi dengan menggunakan kamera Sony RX100 Mark 5 yang mampu menangkap gambar dengan kecepatan maksimum 1000 fps dengan ukuran 1244 x 240 pixels. Pengujian ini bertujuan untuk mengamati bentuk semburan, sudut semburan dan tahapan atomisasi

Pengujian kedua, bertujuan mengetahui karakteristik penguapan air pada sembeuran dengan menggunakan volume udara yang berbeda, atau dengan kata lain rasio udara terhadap air yang berbeda-beda. Pengujian ini dilakukan dengan menghitung selisih antara volume air sebelum diatomisasi dengan volume air yang teratomisasi. 
Instalasi penelitian dapat dilihat pada Gambar 3 . Udara disuplai dari sebuah kompresor (1) yang mengalirakan udara melalui pressure gauge (2), valve (3) dan rotameter (4) menuju nozzle atau airblast atomizer (5). Air dari sebuah tangki (6) dipompa (7) melintasi pressure gauge, valve dan rotameter menuju nozzle penyemprot. Udara dan air bergabung dalam nosel untuk kemudian diinjeksikan ke atomization chamber (8). Spray atau semburan yang terbentuk kemudian direkam menggunakan video kamera (9) yang selanjutnya akan diekstrak gambar-gambar berurutan yang menunjukkan evolusi spray yang dihasilkan.

Adapun spons pada dinding atomization chamber dalam berfungsi untuk membantu menyerap droplet berukuran kecil yang terbentuk selama proses atomisasi.

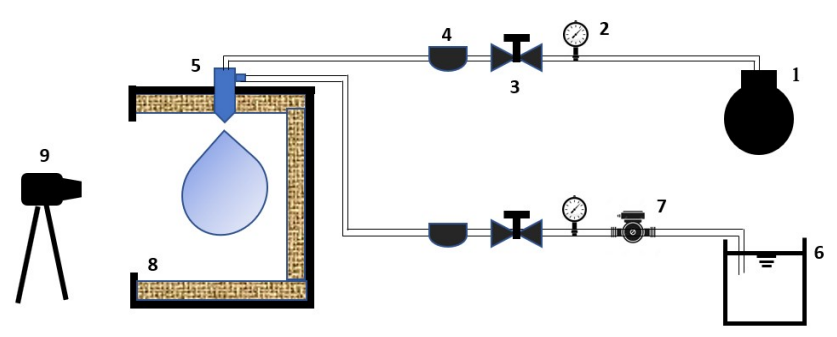

Gambar 3. Peralatan penelitian

Adapun langkah-langkah pengujian yang dilakukan adalah sebagai berikut:

I. Tahap Persiapan

1. Mengisi tangki cairan (liquid) dengan air.

2. Lakukan instalasi pengujian seperti yang ditunjukkan Gambar 1 pada masing-masing pengujian.

II. Tahap Pengujian

A. Pengujian karakteristik geometri semburan pada Airblast Atomizer:

1. Hidupkan kamera. Gunakan mode HFR (High Frame Rate) dengan pilihan warna hitam putih.

2. Hidupkan diaphragm water pump..

3. Atur debit air $0.2 \mathrm{Lpm}$

4. Atur debit udara sesuai rasio yang diujikan.

5. Mulai pengambilan gambar beberapa saat sebelum udara diinjeksikan.

B. Pengujian karakteristik penguapan:

1. Isi air sebanyak $200 \mathrm{~mL}$ pada tangki.

2. Timbang massa awal spons.

3. Atur debit udara sesuai rasio yang diujikan.

4. Atur debit air $0.2 \mathrm{Lpm}$

5. Lama pengujian berlangsung dari awal spray sampai air pada tangki habis.

6. Tampung air hasil atomisasi yang tidak mengendap pada spons.

7. Setelah selesai pengujian, timbang massa spons yang telah terkena spray.

8. Hitung selisih air sebelum dan sesudah atomisas

\section{Hasil dan Pembahasan}

\subsection{Evolusi semburan}

Pengujian telah dilakukan dengan rasio udarabahan bakar masing-masing 1:1, 2:1, 3:1, 4;1, dan 5:1. Masing-masing pengujian telah menghasilkan perekaman gambar evolusi spray sejak awal likuid keluar dari nosel sampai spray terbentuk secara utuh dan stabil. Untuk satu rangkaian pengamatan dihasilkan 1024 gambar spray pada rasio udara-air tertentu. Pembahasan dalam gambar $4 \mathrm{~s} / \mathrm{d} 12 \mathrm{di}$ bawah ini menggunakan frame gambar dari pengujian dengan rasio udara-air 2:1 yang mewakili rasio rendah dan rasio udara-air 4:1 yang mewakili rasio campuran tinggi. Pembahasan dilakukan pada setiap frame untuk menunjukkan perbedaan evolusi spray pada rasio rendah dan tinggi.
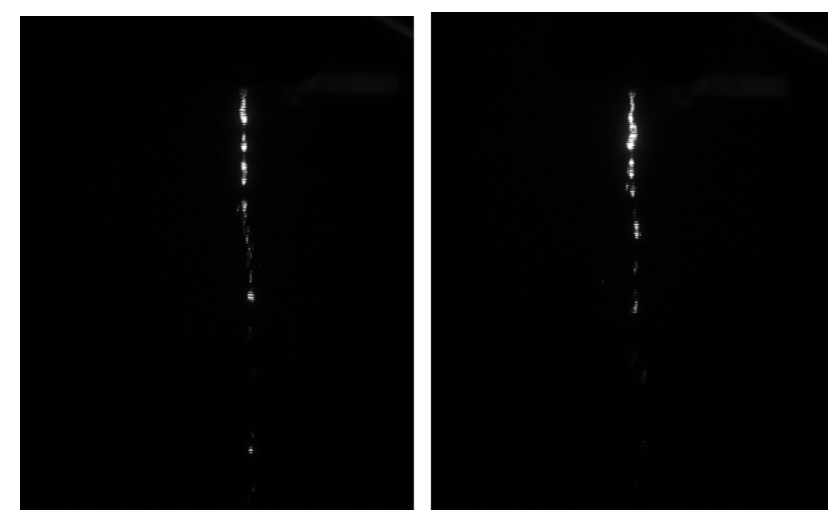

Gambar 4. Ligamen air pada awal injeksi sebelum aliran udara dibuka; rasio udara-air 2:1 (kiri) dan 4:1 (kanan)

Gambar 4 menunjukkan kondisi awal injeksi air, dimana aliran udara masih dalam tahap permulaan dihidupkan dan udara belum ikut keluar nosel. Gambar sebelah kiri (rasio 2:1) terlihat sama dengan gambar sebelah kanan (4:1) karena memang hanya air yang keluar nosel.
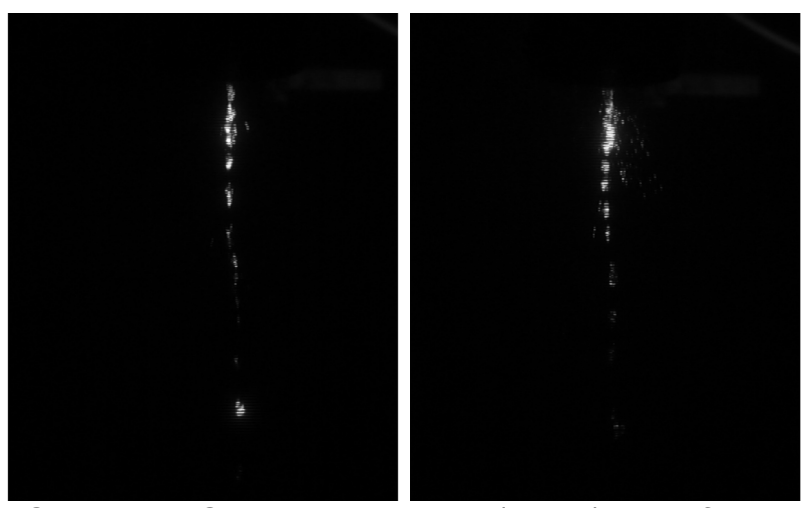

Gambar 5. Gambar semburan (spray) pada frame yang ke 4; rasio udara-air 2:1 (kiri) dan 4:1 (kanan)

Gambar 5 menunjukkan tahap sangat awal kemunculan udara pada ujung nosel, sehingga terlihat ada semburan yang mengarah ke samping membentuk sudut terhadap sumbu nosel. Hal ini menunjukkan terjadinya pencampuran udara-air dan atomisasi pada tahap awal di luar nosel. 

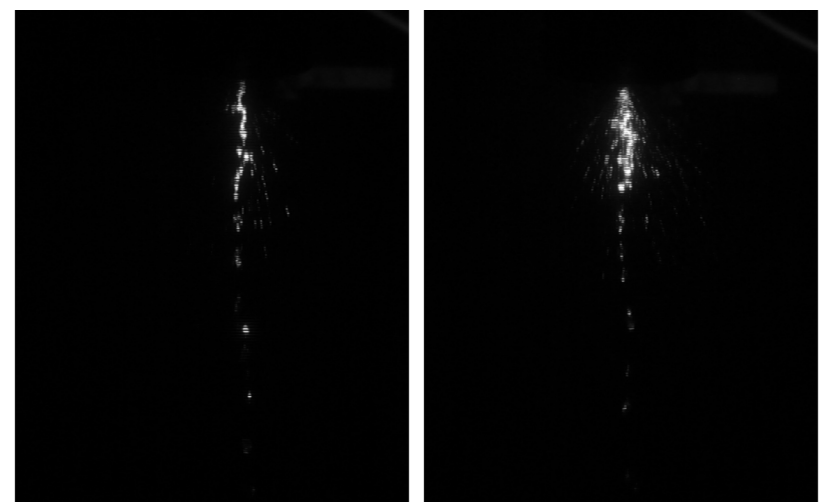

Gambar 6. Gambar semburan (spray) pada frame yang ke 8; rasio udara-air 2:1 (kiri) dan 4:1 (kanan)
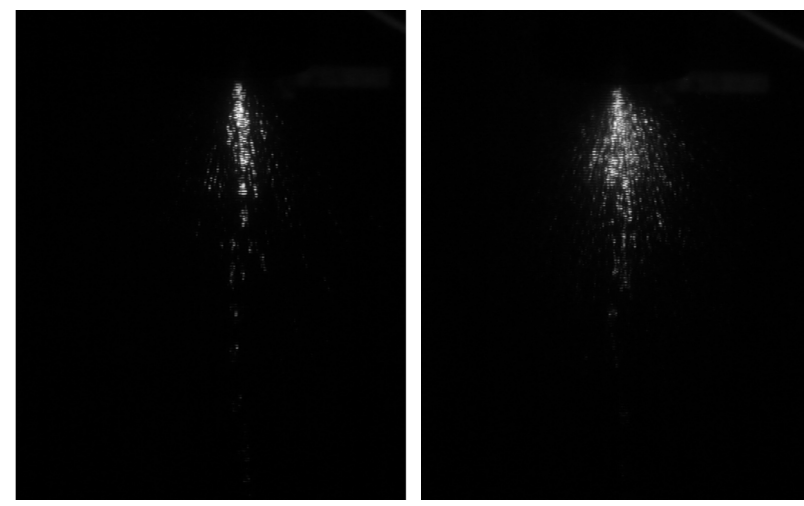

Gambar 7. Gambar semburan (spray) pada frame yang ke 16; rasio udara-air 2:1 (kiri) dan 4:1 (kanan)

Gambar 6 dan 7 menunjukkan kelanjutan atomisasi tahap awal dimana atomisasi terjadi dengan sudut yang lebih lebar, dan mulai terlihat semburan (spray) dalam bentuk droplet yang lebih kecil dan halus terutama untuk rasio udara-air 4:1 (gambar sebelah kanan).

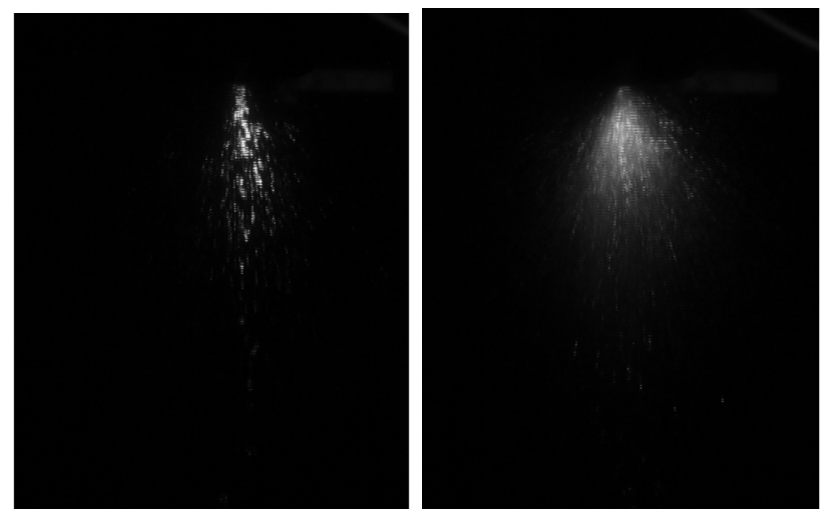

Gambar 8. Gambar semburan (spray) pada frame yang ke 32; rasio udara-air 2:1 (kiri) dan 4:1 (kanan)

Gambar 8 menunjukkan perbedaan yang mencolok atomisasi pada rasio 4:1 terjadi jauh lebih baik dibanding rasio udara-air $2: 1$, meskipun masih terlihat samar droplet berukuran besar pada bagian tengah semburan pada rasio udara-air 4:1. Gambar sebelah kiri (rasio udara-air 2:1) masih menunjukkan dengan jelas droplet yang berukuran besar dalam semburan yang terbentuk.
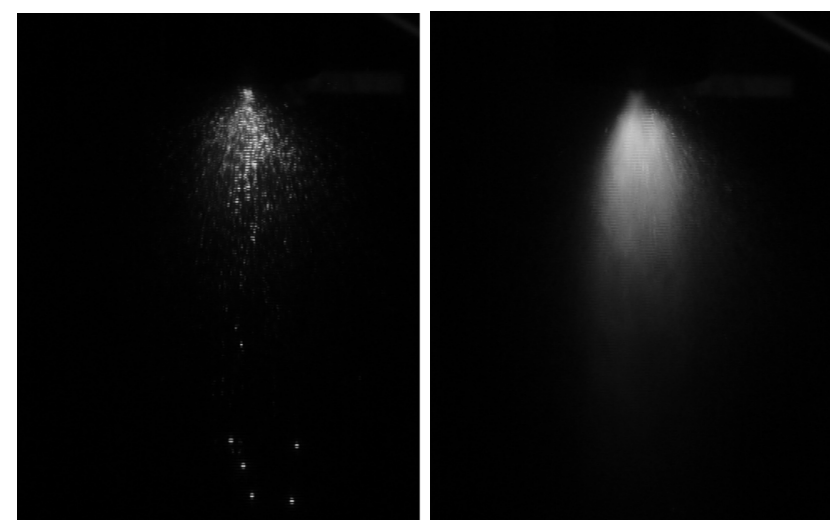

Gambar 9. Gambar semburan (spray) pada frame yang ke 64; rasio udara-air 2:1 (kiri) dan 4:1 (kanan)

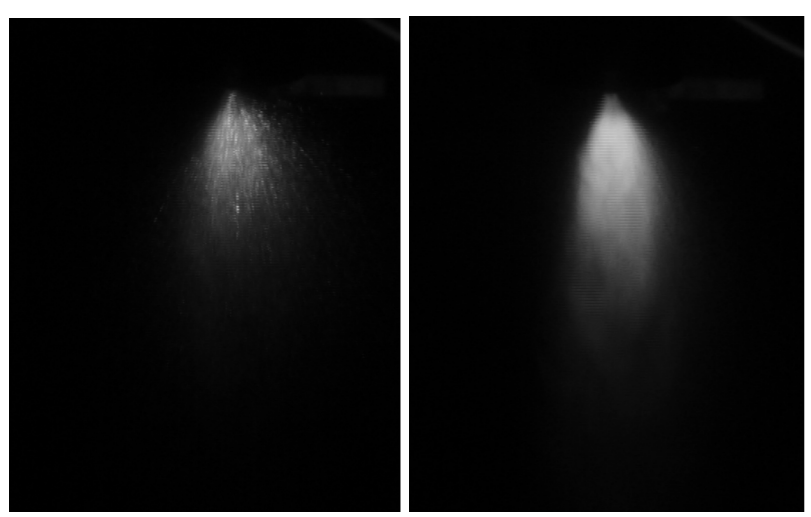

Gambar 10. Gambar semburan (spray) pada frame yang ke 128; rasio udara-air 2:1 (kiri) dan 4:1 (kanan)

Gambar 9 dan 10 menunjukkan kelanjutan atomisasi dan evolusi spray (semburan), baik rasio udara-air rendah dan tinggi. Pada rasio udara-air 2:1 spray sudah terbentuk secara utuh meskipun masih terlihat droplet berukuran besar di bagian tengah semburan; sedangkan pada rasio udara-air 4:1 semburan sudah berkembang penuh dan spray sudah sepenuhnya memperlihatkan ukuran droplet yang hamper sama.

Sampai pada tahap ini, perbandingan kedua gambar menunjukkan bahwa rasio udara-air yang tinggi menghasilkan proses atomisasi yang lebih cepat.
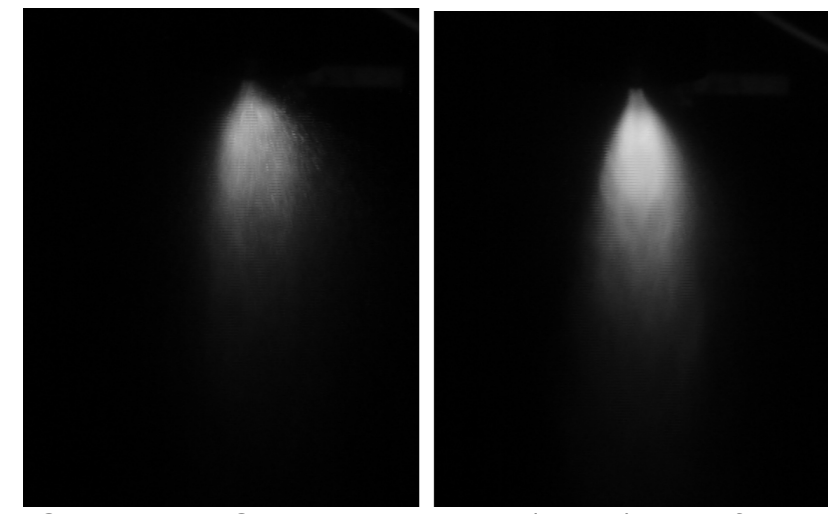

Gambar 11. Gambar semburan (spray) pada frame yang ke 256; rasio udara-air 2:1 (kiri) dan 4:1 (kanan) 


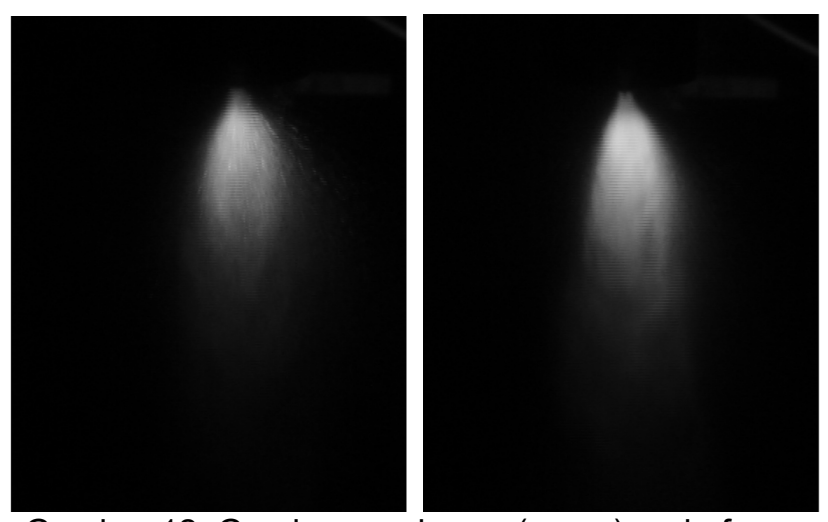

Gambar 12. Gambar semburan (spray) pada frame yang ke 512; rasio udara-air 2:1 (kiri) dan 4:1 (kanan)

Dari Gambar 11 dan 12 menunjukkan gambar semburan (spray) yang kurang lebih bisa dikatakan berkembang penuh baik untuk rasio udara-air 2:1 maupun 4:1. Ukuran droplet yang besar di bagian tengah semburan sudah tidak terlihat lagi, namun rasio udara-air 4:1 menghasilkan luasan spray yang lebih besar dibandingkan rasio 2:1. Hal ini bisa disimpulkan bahwa atomisasi rasio udara-air 4:1 berlangsung lebih baik, karena diasumsikan droplet yang berukuran besar akan lebih cepat jatuh dan tidak terekam oleh kamera.

\subsection{Perbandingan geometri spray pada semua rasio} udara-air

Gambar 13 s/d 17 menunjukkan gambar pada frame ke 512 yang terekam untuk rasio udara-air 2:1 sampai 5:1. Dari Gambar 13 terlihat dalam kondisi berkembang penuh, semburan dengan rasio 1:1 masih memperlihatkan droplet berukuran besar di dalam semburan, dan sebagai dampaknya ukuran spray relatif lebih kecil dibanding yang lainnya. Dalam aplikasi pembakaran hal ini tidak diinginkan karena droplet berukuran besar akan menghasilkan pembakaran tidak sempurna atau bisa juga tidak selesai sampai bahan bakar habis.

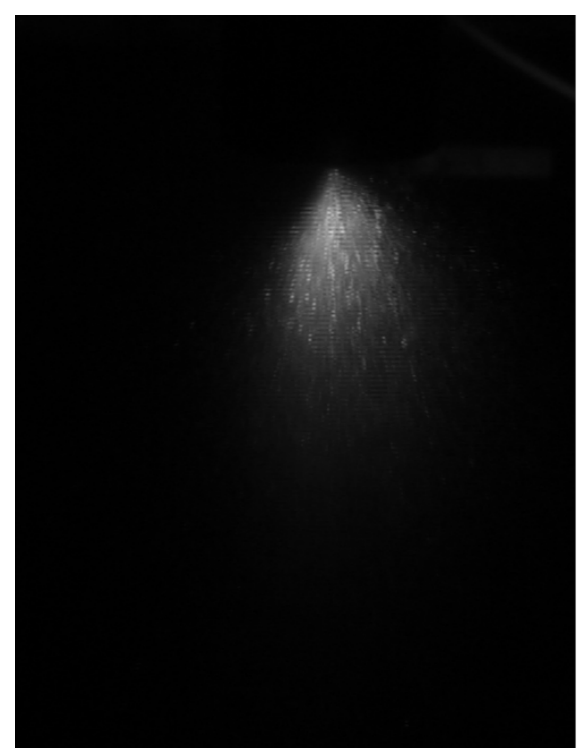

Gambar 13. Spray rasio udara-air 1:1 (frame ke 512)

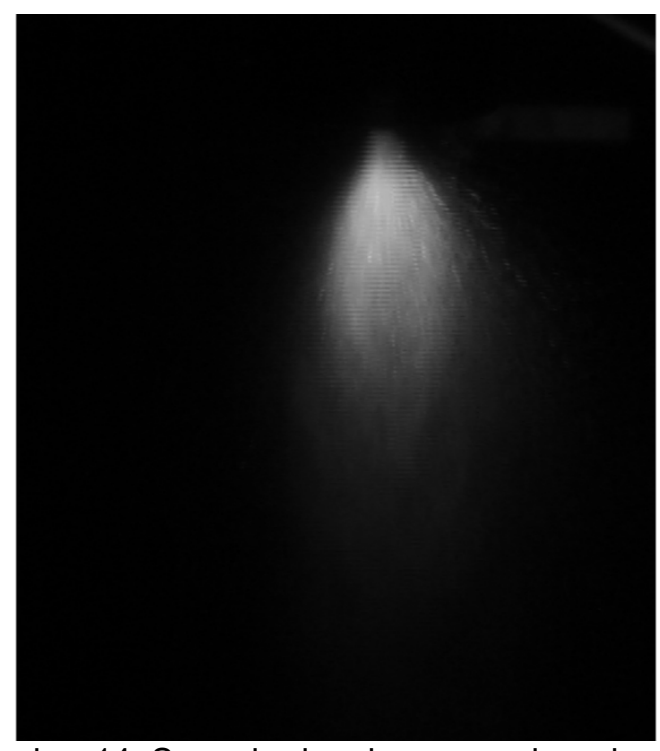

Gambar 14. Spray berkembang penuh pada rasio udara-air 2:1 (frame ke 512)

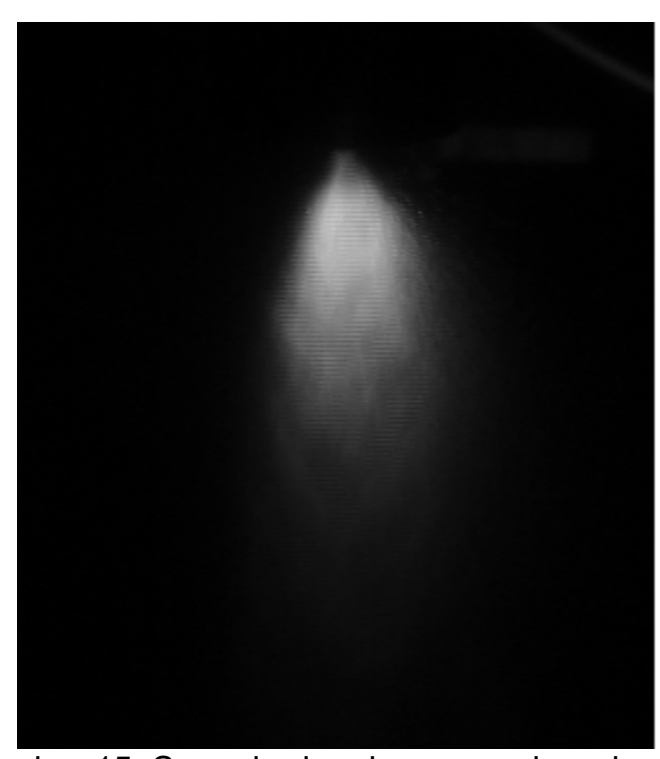

Gambar 15. Spray berkembang penuh pada rasio udara-air 3:1 (frame ke 512)

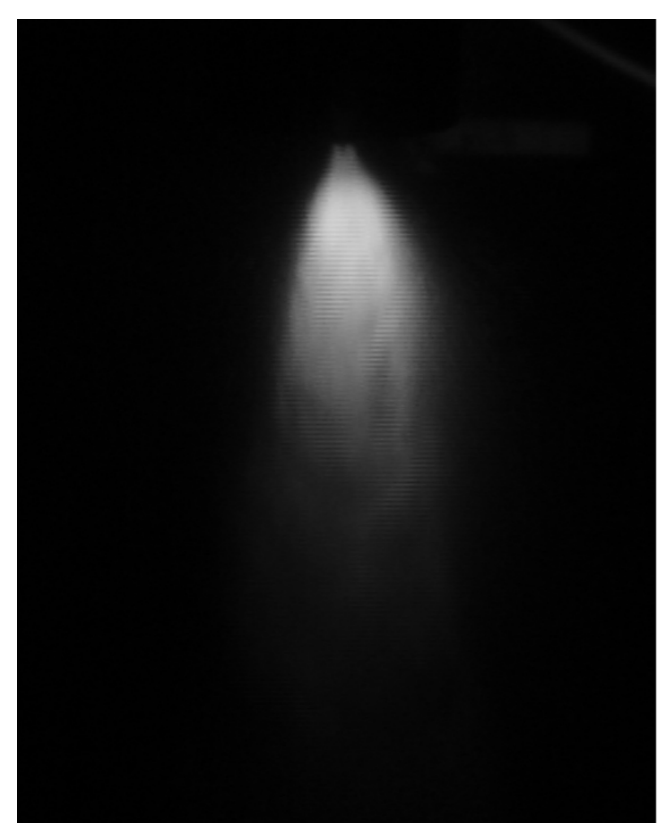

Gambar 16. Spray berkembang penuh pada rasio udara-air 4:1 (frame ke 512) 


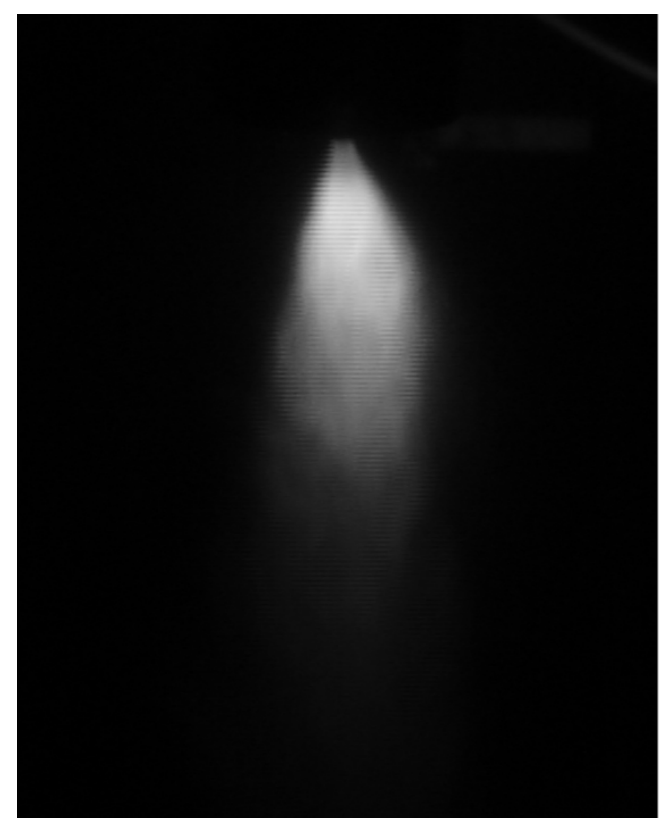

Gambar 17. Spray berkembang penuh pada rasio udara-air 5:1 (frame ke 512)

Dalam Gambar 14 s/d 17 semburan yang terjadi jauh lebih baik dibanding Gambar 13 (rasio 1:1), meskipun dalam Gambar 14 (rasio 2:1) semburan yang dihasilkan masih terlihat lebih kasar (yang berarti droplet berukuran besar) dibandingkan rasio $3: 1 \mathrm{~s} / \mathrm{d}$ 5:1. Semakin tinggi rasio udara-air, semburan terlihat makin halus dan terbentuknya sudut spray yang lebih kecil. Konsekuensi selanjutnya dari kondisi ini adalah ukuran droplet yang semakin kecil dan penguapan yang terjadi secara lebih baik pada rasio udara-air yang lebih tinggi. Droplet yang lebih kecil akan lebih mudah menguap ketika mengalami kontak dengan udara. Dalam aplikasi pembakaran droplet yang lebih kecil ini akan lebih mudah terbakar dan menghasilkan pembakaran yang lebih baik.

\section{Kesimpulan}

Pengujian eksperimental telah dilakukan untuk menguji sebuah airblast atomizer untuk mendapatkan karakteristik semburan (spray) campuran udara-air denrang rasio udara-air 1:1 s/d 5:1. Air mewakili bahan bakar cair dalam penggunaan sebenarnya. Dalam penelitian udara dan air dicampur didalam nosel/airblast atomizer sebelum disemprotkan keluar nosel. Spray atau semburan yang terbentuk direkam dengan video kamera kecepatan tinggi untuk mendapatkan evolusi spray frame demi frame. Hasil pengamatan dan analisis gambar spray menunjukkan bahwa rasio udara-air mempengaruhi karakteristik atomisasi yang terjadi (dimensi spray dan tingkat penguapan) yang dijelaskan dalam analisis gambar evolusi semprotan mulai dari kemunculan awal di ujung nosel sampai terbentuk spray yang stabil. Analisis gambar evolusi spray menunjukkan bahwa rasio udara-air yang tinggi menghasilkan sudut semprotan yang kecil, atomisasi yang lebih cepat, dan ukuran droplet yang lebih kecil.

\section{Ucapan Terima Kasih}

Makalah ini merupakan bagian dari Penelitian Unggulan Udayana 2017. Ucapan terima kasih kami sampaikan kepada Lembaga Penelitian dan Pengabdian kepada Masyarakat Universitas Udayana atas pendanaan yang diberikan; serta tak lupa kami ucapkan terima kasih kepada mahasiswa PS Teknik Mesin Raymond Nicholas Silalahi, M. Dwi Ergianto, dan Jhon Rio Halasan Simbolon yang telah membantu dalam pelaksanaan penelitian.

\section{Daftar Pustaka}

[1] Schick, R. J. (1997) Spray Technology Reference Guide: Understanding Drop Size Preface, 47th Chemical Processing Industry Exposition, p. 6. doi: 10.1016/S0022-3913 (12) 00047-9.

[2] Lefebvre, Arthur H. (1989) Atomization and Sprays, Hemisphere Pub. Corp.

[3] Williams, A. (1990) Combustion of liquid fuel sprays, Butterworths (Canada) Limited.

[4] Graco, I. (1995) Atomization: Concept and Theory Training, p. 14.

[5] Somerkallio, M. (2011) SPRAY APPLICATION OF STRENGTH CHEMICALS Master of Science Thesis', (October).

[6] Ghurri, A., Adhi Suryawan, A. A. and Tua Sagala, B. (2015) Pengaruh Jumlah Lilitan Pipa Sebagai Pemanasan Awal Pada Kompor Pembakar Jenazah. Proceeding Seminar Nasional Tahunan Teknik Mesin XIV.

[7] Olusegun Adefonabi Adefuye, Benneth Ifenna Okoli (2017), Design and Evaluation of an Air-blast atomizer, International Journal of Science and Engineering Applications, Vol. 6, Issue 12, p. 364371. 